\title{
PENENTUAN KAPASITAS JALAN ENAM LAJUR DUA ARAH TERBAGI DAN TAK TERBAGI DENGAN METODE MKJI, KONSEP PKJI, DAN SURVEI
}

\author{
Dennis Anugrah Kurniawan' ${ }^{1}$ dan Najid ${ }^{2}$ \\ ${ }^{1}$ Program Studi Sarjana Teknik Sipil, Universitas Tarumanagara, Jl. Letjen S. Parman No.1 Jakarta \\ dennis.anugrah96@gmail.com \\ ${ }^{2}$ Program Studi Sarjana Teknik Sipil, Universitas Tarumanagara, Jl. Letjen S. Parman No.1 Jakarta \\ najid2009@yahoo.com
}

\begin{abstract}
ABSTRAK
Dalam perkembangannya Indonesia mempunyai pertumbuhan penduduk yang sangat tinggi sehingga hal tersebut akan langsung berdampak kepada kinerja lalu lintas. Hal ini membuat pemerintah membuat sebuah konsep baru untuk menghitung nilai kapasitas jalan dan kecepatan arus bebas yaitu dengan konsep PKJI yang diharapkan sebagai penggan MKJI yang telah digunakan sejak tahun 1997. Jumlah penduduk jelas berpengaruh sangat besar terhadap nilai kapasitas jalan dan kecepatan arus bebas dikarenakan dengan perbedaan jumlah penduduk maka akan berbeda mulai dari perilaku pengemudi dan populasi kendaraannya. Sedangkan hambatan samping merupakan dampak terhadap kinerja lalu lintas yang berasal dari aktivitas samping segmen jalan.Hambatan samping yang pada umumnya mempengaruhi kapasitas jalan adalah pejalan kaki, kendaraan parkir dan berhenti,kendaraan keluarmasuk dan kendaraan tidak bermotor. Jalan Bungur Besar Raya, Jalan Danau Sunter Selatan, Jalan Biak Roxy , Jl Hj. Encep Nawawi dijadikan wilayah studi pada penelitian ini terkait beberapa hal, di antaranya adalah pada ruas jalan tersebut terdapat beberapa penggunaan tata guna lahan yang berbeda, dan belum adanya penelitian tentang pengaruh hambatan samping, dan ukuran kota terhadap volume dan kecepatan lalu lintas di ruas jalan tersebut.Penelitian dilakukan dengan cara survei volume lalu lintas harian. Data primer yang digunakan adalah volume lalu lintas, jumlah hambatan samping, dan kecepatan rata-rata kendaraan. Data-data tersebut diolah dengan metode Green Shield untuk mendapatkan nilai kapasitas dari survei untuk dibandingkan dengan MKJI.
\end{abstract}

Kata kunci:,Ukuran kota, Hambatan Samping, Volume Lalu Lintas, Kecepatan Lalu Lintas, Kapasitas.

\section{PENDAHULUAN}

\section{Latar Belakang}

Kapasitas didalam Manual Kapasitas Jalan Indonesia (1997) menurut arus maksimum yang melewati suatu titik pada jalan bebas hambatan yang dapat dipertahankan persatuan jam dalam kondisi yang berlaku. Untuk jalan bebas hambatan tak terbagi, kapasitas adalah arus maksimum dua-arah (kombinasikedua arah), untuk jalan bebas hambatan terbagi kapasitas adalah arus maksimum perlajur. Kapasitas jalan dipengaruhi oleh berbagai macam faktor seperti lebar jalan, median jalan, hambatan samping, ukuran kota.

Di Indonesia saat ini masih menggunakan Manual Kapasitas Jalan Indonesia (MKJI) sebagai acauan untuk menghitung kapasitas jalan sedangkan untuk sekarang ini dengan perkembangan di kota besar di Indonesia maka volume yang digunakan sudah tidak sesuai lagi. Dengan perkembangan volume yang ada maka pemerintah mengikutinya dengan mengeluarkan konsep Pedoman Kapasitas Jalan Indonesi (PKJI) pada taahun 2014.

\section{Tujuan Penelitian}

Berdasarkan latar belakang, Tujuan dalam penelitian ini adalah menganalisis kapasitas jalan menggunakan MKJ; menganalisis kapasitas jalan menggunakan konsep PKJI; menganalisis kapasitas jalan dengan menggunakan model dari hasil survei. membandingkan kapasitas hasil survei dengan MKJI.

\section{Kapasitas Jalan Menurut MKJI}

Kapasitas jalan didefiniskan sebagai arus maksimum yang melewati suatu titik dijalan yang dapat dipertahankan per satuan jam pada kondisi tertentu. Adapun sekarang ini kita masih menggunakan Manual Kapasitas Jalan Indonesia (MKJI) sejak tahun 1997 dan ada konsep Pedoman Kapasitas Jalan Indonesia (PKJI) yang dibuat untuk memuktahirkan perhitungan MKJI. Beberapa hal yang mempengaruhi kapasitas jalan adalah kapasitas dasar, lebar jalan, ada atau tidak ada pemisah jalan. jenis hambatan samping, ukuran kota. Sehingga didapat rumus: 
Survei

Dengan:

$$
\mathrm{C}=\mathrm{C}_{\mathrm{O}} \times \mathrm{FC}_{\mathrm{W}} \times \mathrm{FC}_{\mathrm{SP}} \times \mathrm{FC}_{\mathrm{SF}} \times \mathrm{FC}_{\mathrm{CS}}
$$

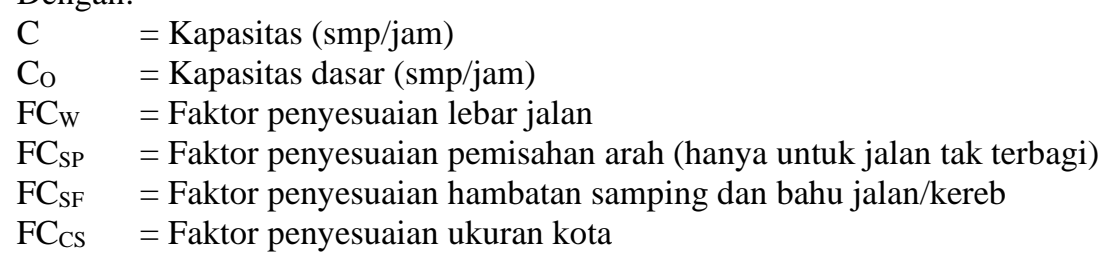

\section{Hambatan Samping Menurut MKJI}

Hambatan samping merupakan salah satu faktor yang mempengaruhi penurunan kapasitas dan kinerja jalan (Alamsyah, 2008). Hambatan samping ini terbagi menjadi 4 kategori berbeda dengan bobot yang berbeda seperti pada Tabel 1.

Tabel 1. Penentuan Tipe Frekuensi Kejadian Hambatan Samping (Sumber:MKJI 1997)

\begin{tabular}{lcc}
\hline Tipe kejadian hambatan samping & Simbol & Faktor bobot \\
\hline Pejalan kaki & PED & 0.5 \\
Kendaraan parkir & PSV & 1.0 \\
Kendaraan masuk dan keluar sisi jalan & EEV & 0.7 \\
Kendaran lambat & SMV & 0.4 \\
\hline
\end{tabular}

Tingkatan hambatan samping setelah dikalikan dengan bobot diatas dibagi menjadi lima kelas. Kelas tersebut akan mempengaruhi kapasitas jalan dan juga akan mempengaruhi kecepatan arus bebas suatu jalan Tabel 2 akan menunjukan kelas-kelas hambatan samping.

Tabel 2. Nilai Kelas Hambatan Samping (sumber:MKJI 1997)

\begin{tabular}{|c|c|c|c|}
\hline $\begin{array}{c}\text { Kelas Hambatan Samping } \\
\text { (SCF) }\end{array}$ & Kode & $\begin{array}{l}\text { Jumlah kejadian per } \\
\text { 200m per jam }\end{array}$ & Kondisi daerah \\
\hline Sangat Rendah & $\mathrm{VL}$ & $<100$ & Daerah pemukiman; hampir tidak ada kegitan \\
\hline Rendah & $\mathrm{L}$ & $100-299$ & $\begin{array}{l}\text { Daerah pemukiman; berupa angkutan umum } \\
\text { dan sebagainya }\end{array}$ \\
\hline Sedang & M & $300-499$ & Daerah industri; beberapa toko di sisi jalan \\
\hline Tinggi & $\mathrm{H}$ & $500-899$ & $\begin{array}{l}\text { Daerah komersial; aktivitas sisi jalan yang } \\
\text { sangat tinggi }\end{array}$ \\
\hline Sangat tinggi & VH & $>900$ & $\begin{array}{l}\text { Daerah komersial; aktivitas pasar disamping } \\
\text { jalan }\end{array}$ \\
\hline
\end{tabular}

\section{Kecepatan Arus Bebas Menurut MKJI}

Kecepatan arus bebas adalah kecepatan pada tingkat arus nol, yaitu kecepatan yang akan dipilih pengemudi jika mengendarai kendaraan bermotor tanpa dipengaruhi kendaraan yang lain (volume =1). Kecepatan arus bebas dapat dihitung dengan persamaan matematis yang terdapat pada MKJI (1997) dengan mempertimbangkan data geometrik serta kondisi lingkungan jalan. Kecepatan arus bebas dapat dicari menggunakan persamaan :

$$
\mathrm{FV}=(\mathrm{FVo}+\mathrm{FVw}) \times \text { FFVsf } x \text { FFVcs }
$$

Dengan:

$\mathrm{FV} \quad=$ Kecepatan arus bebas untuk kendaraan ringan dalam kondisi aktual

$\mathrm{FVo} \quad=$ kecepatan dasar arus bebas untuk kendaraan ringan $(\mathrm{km} / \mathrm{jam})$

$\mathrm{FVw}=$ faktor penyesuaian kecepatan untuk lebar jalan $(\mathrm{km} / \mathrm{jam})$

FFVsf = faktor penyesuaian untuk hambatan samping dan bahu atau kereb jalan

FFVcs $=$ faktor penyesuaian kecepatan untuk ukuran kota

\section{Kapasitas Jalan Menurut PKJI}

Kapasitas jalan adalah kemampuan ruas jalan untuk menampung arus atau volume lalu lintas yang ideal dalam satuan waktu tertentu. Kapasitas jalan merupakan arus lalu lintas maksimum dalam satuan ekr/jam yang dapat dipertahankan sepanjang segmen jalan tertentu dalam kondisi tertentu, yaitu yang melingkupi geometrik, lingkungan dan faktor 
lingkungan (PKJI, 2014). Penetapan kapasitas(C) menurut PKJI 2014 untuk tipe jalan 2/2TT, C ditentukan untuk total arus dua arah. Untuk jalan tipe 4/2T, 6/2T, dan 8/2T, arus ditentukan secara terpisah per arah dan kapasitas ditentukan per lajur. Kapasitas segmen dapat dihitung menggunakan persamaan :

Dengan:

$$
\mathrm{C}=\mathrm{C}_{0} \times \mathrm{FC}_{\mathrm{LJ}} \times \mathrm{FC}_{\mathrm{PA}} \times \mathrm{FC}_{\mathrm{HS}} \times \mathrm{FC}_{\mathrm{UK}}
$$

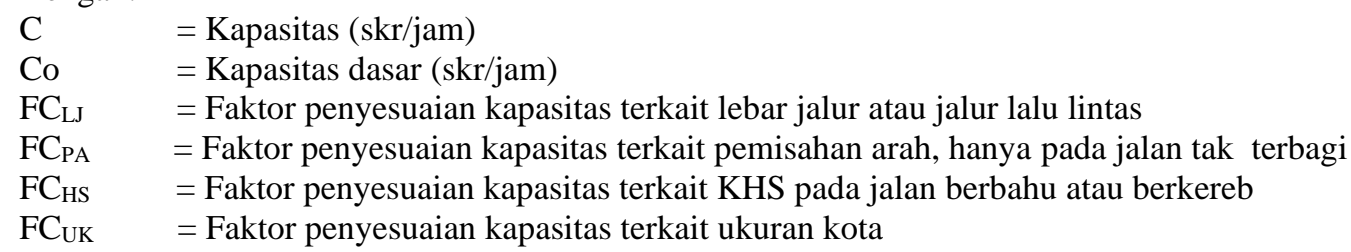

\section{Kecepatan Arus Bebas Menurut PKJI}

Kecepatan suatu kendaraan yang tidak terpengaruh oleh kehadiran kendaraan lain, yaitu kecepatan dimana pengemudi merasa nyaman untuk bergerak pada kondisi geometric, lingkungan dan pengendalian lalu lintas yang ada pada suatu segmen jalan tanpa lalu lintas lain. Nilai VB jenis KR ditetapkan sebagai kriteria dasar untuk kinerja segmen jalan, nilai VB untuk KB dan SM ditetapkan hanya sebagai referensi. VB untuk KR biasanya 10-15\% lebih tinggi dari tipe kendaraan lainnya. VB dihitung menggunakan persamaan :

Dengan:

$$
\mathrm{V}_{\mathrm{B}}=\left(\mathrm{V}_{\mathrm{BD}}+\mathrm{V}_{\mathrm{BL}}\right) \times \mathrm{FV}_{\mathrm{BHS}} \times \mathrm{FV}_{\mathrm{BUK}}
$$

$\mathrm{V}_{\mathrm{B}} \quad=$ Kecepatan arus bebas untuk kendaraan ringan dalam kondisi aktual

$\mathrm{V}_{\mathrm{BD}} \quad=$ kecepatan dasar arus bebas untuk kendaraan ringan $(\mathrm{km} / \mathrm{jam})$

$\mathrm{V}_{\mathrm{BL}} \quad$ = faktor penyesuaian kecepatan untuk lebar jalan $(\mathrm{km} / \mathrm{jam})$

$\mathrm{FV}_{\mathrm{BHS}}=$ faktor penyesuaian untuk hambatan samping dan bahu atau kereb jalan

$\mathrm{FV}_{\mathrm{BUK}}=$ faktor penyesuaian kecepatan untuk ukuran kota

\section{Hambatan Samping Menurut PKJI}

Hambatan samping adalah kegiatan di samping segmen jalan yang berpengaruh terhadap kinerja lalu lintas (PKJI 2014). Hambatan samping ini terbagi menjadi 4 kategori berbeda dengan bobot yang berbeda seperti pada Tabel 3.

Tabel 3. Pembobotan Hambatan Samping (Sumber:PKJI 2014 : 28)

\begin{tabular}{lc}
\hline \multicolumn{1}{c}{ Jenis hambatan samping } & Faktor bobot \\
\hline Pejalan kaki di badan jalan dan yang menyebrang & 0.5 \\
Kendaraan umum dan kendaraan lainnya yang berhenti & 1.0 \\
Kendaraan keluar/masuk sisi atau lahan samping jalan & 0.7 \\
Arus kendaraan lambat (kendaraan tak bermotor) & 0.4 \\
\hline
\end{tabular}

Tingkatan hambatan samping setelah dikalikan dengan bobot diatas dibagi menjadi lima kelas. Kelas tersebut akan mempengaruhi kapasitas jalan dan juga akan mempengaruhi kecepatan arus bebas suatu jalan.Tabel 4 akan menunjukan kelas-kelas hambatan samping.

\begin{tabular}{|c|c|c|c|}
\hline Kelas Hambatan Samping & Kode & $\begin{array}{l}\text { Jumlah kejadian per } \\
200 \mathrm{~m} \text { per jam }\end{array}$ & Kondisi daerah \\
\hline Sangat Rendah & SR & $<100$ & Daerah pemukiman, tersedia jalan lingkungan \\
\hline Rendah & $\mathrm{R}$ & $100-299$ & $\begin{array}{l}\text { Daerah pemukiman, ada beberapa angkutan } \\
\text { umum }\end{array}$ \\
\hline Sedang & $S$ & $300-499$ & $\begin{array}{l}\text { Daerah industry, ada beberapa toko di } \\
\text { sepanjang sisi jalan }\end{array}$ \\
\hline Tinggi & $\mathrm{T}$ & $500-899$ & $\begin{array}{l}\text { Daerah komersial, ada aktivitas sisi jalan yang } \\
\text { tinggi }\end{array}$ \\
\hline Sangat tinggi & $\mathrm{ST}$ & $>900$ & Daerah komersial; ada aktivitas pasar sisi jalan \\
\hline
\end{tabular}

Tabel 4. Kriteria Kelas Hambatan Samping (sumber:PKJI 2014 : 28) 
Dan Tak Terbagi Dengan Metode MKJI, Konsep PKJI, Dan

Survei

\section{METODOLOGI PENELITIAN}

\section{Metode Pengumpulan Data}

Sumber data penelitian yang diperoleh melalui media perantara atau secara tidak langsung yang berupa buku, catatan, bukti yang telah ada, atau arsip baik yang dipublikasikan maupun yang tidak dipublikasikan secara umum. Dengan kata lain, peneliti membutuhkan pengumpulan data dengan cara berkunjung ke perpustakaan, pusat kajian, pusat arsip atau membaca banyak buku yang berhubungan dengan penelitiannya. Seperti MKJI dan konsep PKJI, sebagai pedoman dari nilai bobot dan faktor bobot yang akan dibandingkan dengan data primer yang akan didapat setelah melakukan observasi dan menganalisis data. Data observasi didapat dengan menghitung jumlah kedaraan yang lewat pada 1 titik untuk mendapatkan volume lalu lintas, menghitung kecepatan dengan menggunakan jarak 200m, menghitung jumlah kejadian yang terdapat pada klasifikasi hambatan samping dalam jarak 200m untuk mendapatkan nilai hambatan samping.

\section{Metode Analisis Data}

Metode analisis yang digunakan untuk menganalisa data observasi menggunakan Microsoft excel untuk mengolah data-data yang didapatkan dari observasi lapangan. Sebelum dilakukan analisis data, perlu adanya studi literatur dengan mencari dasar-dasar teori dan sumber data untuk mendapatkan rumus-rumus yang diperlukan.

Dalam Metode ini akan dianalisis jalan dengan menggunakan metode MKJI dan konsep PKJI yang nanti akan digunakan untuk membandingkan dengan hasil observasi. MKJI dan konsep PKJI akan digunakan untuk memberikan angka-angka faktor pengaruh yang akan digunakan untuk mendapatkan hasil kapasitas dan kecepatan arus bebas.

\section{ANALISIS DAN PEMBAHASAN}

\section{Derajat Kejenuhan (Q/C) dan Kepadatan Lalu Lintas (D)}

Derajat kejenuhan didapat dengan membagi volume lalu lintas dengan kapasitas jalan (Q/C), sedangkan kepadatan lalu lintas diperoleh dengan membagi volume lalu lintas dengan kecepatan rata-rata (Q/Vrata-rata). Derajat kejenuhan dan kepadatan lalu lintas pada jalan Bungur Besar Raya dapat dilihat pada Tabel 5.

Tabel 5. Performa dan Kepadatan Lalu Lintas Jalan Bungur Besar

\begin{tabular}{ccccccc}
\hline Jalan & \multicolumn{7}{c}{ Bungur } \\
\hline Tata Guna Lahan Kiri & \multicolumn{7}{c}{ Ruko } \\
\hline Tata Guna Lahan Kanan & C & Q & V rata-rata & FV & Q/C & D \\
\hline Pukul & 3192 & 617.4 & 26.68 & 53.82 & 0.1874 & 23.13661 \\
\hline $06.00-07.00$ & 3192 & 599.1 & 26.68 & 53.82 & 0.1818 & 22.45083 \\
$06.15-07.15$ & 3192 & 574.3 & 26.45 & 53.82 & 0.1799 & 21.71522 \\
$06.30-07.30$ & 3192 & 648.9 & 26.68 & 53.82 & 0.2033 & 24.31705 \\
$06.45-07.45$ & 3192 & 709.7 & 27.22 & 53.82 & 0.2224 & 26.07435 \\
$07.00-08.00$ & 3192 & 869 & 25.27 & 53.82 & 0.2723 & 34.38733 \\
$11.00-12.00$ & 3192 & 934.1 & 24.84 & 53.82 & 0.2927 & 37.60109 \\
$11.15-12.15$ & 3192 & 898.6 & 25.56 & 53.82 & 0.2815 & 35.1585 \\
$11.30-12.30$ & 3192 & 892.7 & 25.35 & 53.82 & 0.2797 & 35.2127 \\
11.45 .12 .45 & 3192 & 810.3 & 25.13 & 53.82 & 0.2539 & 32.24436 \\
$13.00-14.00$ & 3192 & 990.5 & 24.24 & 53.82 & 0.3103 & 40.8706 \\
$17.00-18.00$ & 3192 & 1067 & 23.86 & 53.82 & 0.3343 & 44.71915 \\
$17.15-18.15$ & 3192 & 1207.6 & 23.24 & 53.82 & 0.3783 & 51.96682 \\
$17.30-18.30$ & 3192 & 1101.25 & 23.24 & 53.82 & 0.3450 & 47.39025 \\
$17.45-18.45$ & 3192 & 1105.7 & 23.43 & 53.82 & 0.3464 & 47.18871 \\
\hline $18.00-19.00$ & & & &
\end{tabular}

Dari Tabel 5 dapat juga diambil perbandingan antara kepadatan dengan kecepatan rata-rata pada Jalan Bungur Besar Raya untuk menghitung kapasitas jalan pada jalan tersebut. Perbandingan kepadatan dengan kecepatan rata-rata dapat dilihat pada Gambar 1. 


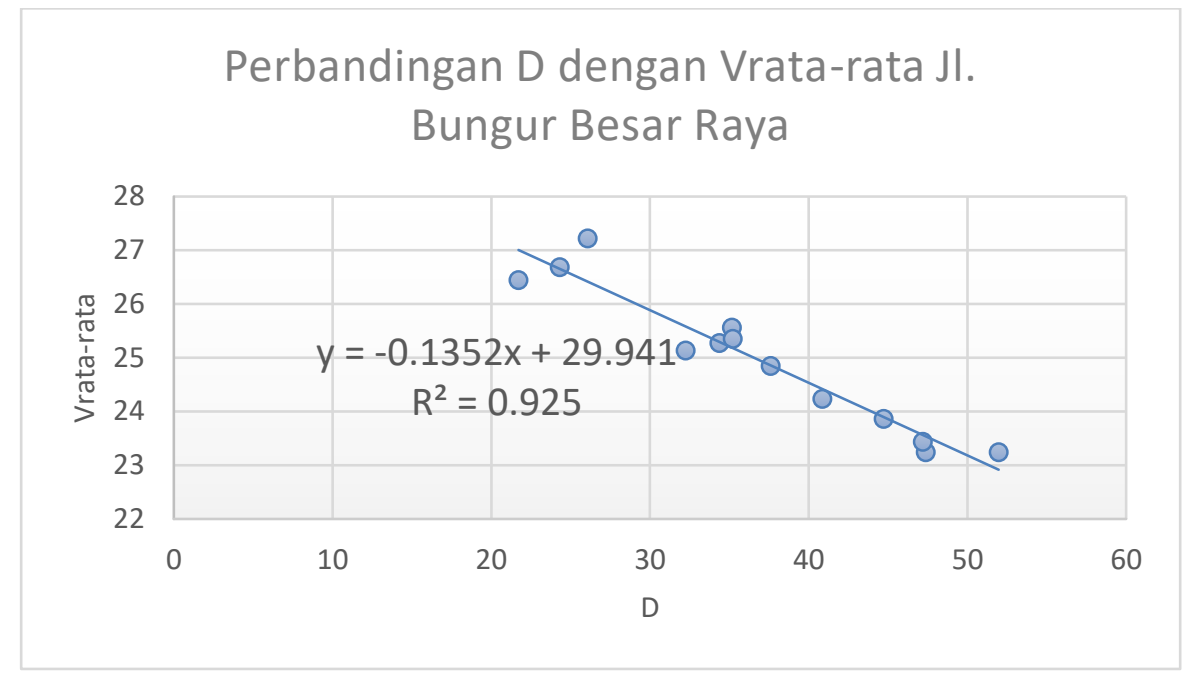

Gambar 1. Perbandingan D Dengan V Rata-Rata Bungur Besar Raya

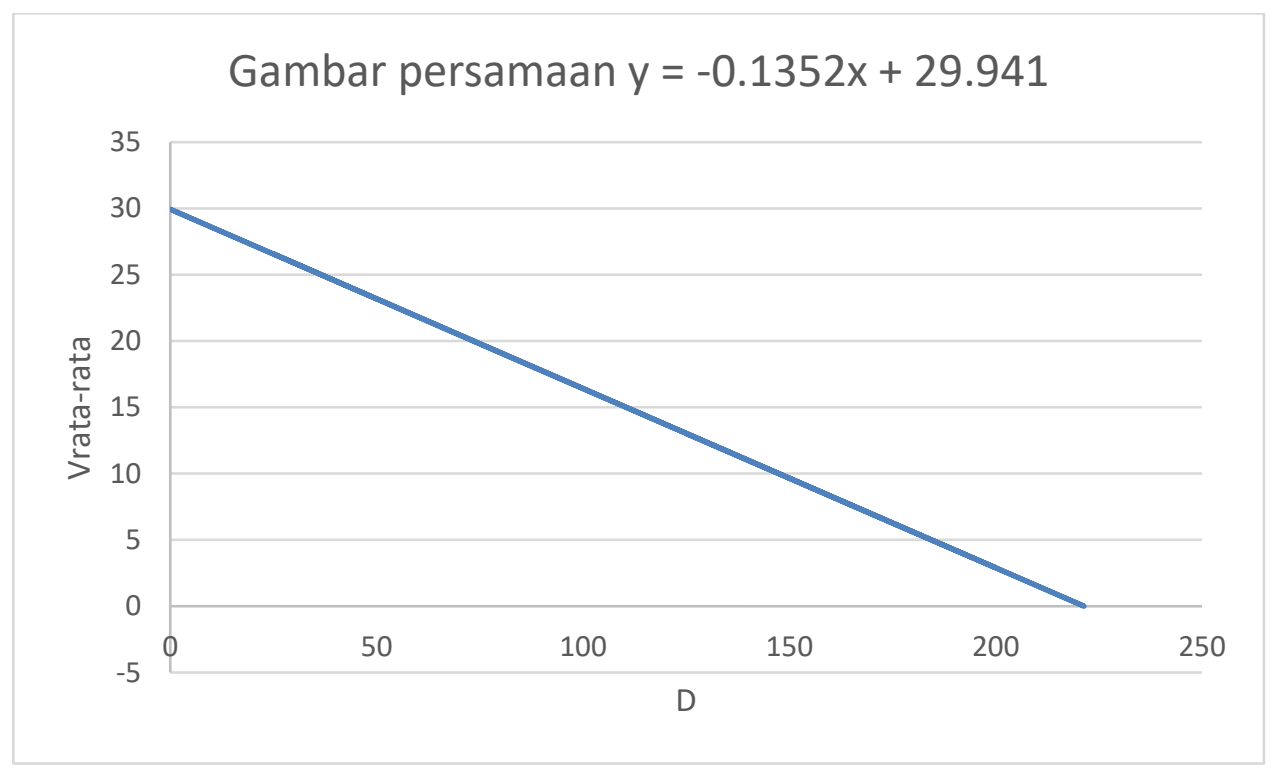

Gambar 2. Hubungan kepadatan dengan kecepatan

Dari Gambar 2 maka didapatkan nilai Dj 221.4652 kendaraan/km yang merupakan nilai x maksimum, dan Vf 29.941 $\mathrm{km} / \mathrm{jam}$ yang merupakan nilai y maksimum maka C yang didapatkan 1658 kendaraan.

Performa dan kepadatan lalu lintas pada Jalan Danau Sunter Selatan dapat dilihat pada Tabel 6. 
Penentuan Kapasitas Jalan Empat Lajur Dua Arah Terbagi

Dan Tak Terbagi Dengan Metode MKJI, Konsep PKJI, Dan

Survei

Tabel 6. Performa dan Kepadatan Lalu Lintas Jalan Danau Sunter Selatan

\begin{tabular}{ccccccc}
\hline Jalan & \multicolumn{7}{c}{ Danau Sunter } \\
\hline Tata Guna Lahan Kiri & \multicolumn{5}{c}{ Rumah } \\
\hline Tata Guna Lahan Kanan & C & Q & V rata-rata & FV & Q/C & D $(\mathrm{Q} / \mathrm{V})$ \\
\hline Pukul & 3329 & 1491.7 & 23.43 & 60.47 & 0.4221 & 63.662 \\
\hline $06.00-07.00$ & 3329 & 1506.7 & 23.24 & 60.47 & 0.4264 & 64.838 \\
$06.15-07.15$ & 3295 & 1551.7 & 22.89 & 59.88 & 0.4436 & 67.801 \\
$06.30-07.30$ & 3295 & 1606.75 & 22.45 & 59.88 & 0.4593 & 67.485 \\
$06.45-07.45$ & 3295 & 1703.1 & 22.82 & 59.884 & 0.4869 & 70.988 \\
$07.00-08.00$ & 3295 & 1357.1 & 23.85 & 59.884 & 0.3880 & 59.296 \\
$11.00-12.00$ & 3295 & 1385.0 & 23.64 & 59.884 & 0.3959 & 58.589 \\
$11.15-12.15$ & 3295 & 1404.3 & 23.64 & 59.884 & 0.4015 & 59.408 \\
$11.30-12.30$ & 3295 & 1465.9 & 23.43 & 59.884 & 0.4191 & 62.012 \\
11.45 .12 .45 & 3295 & 1472.6 & 23.32 & 59.884 & 0.4210 & 62.295 \\
$13.00-14.00$ & 3295 & 1742.1 & 22.54 & 59.884 & 0.4980 & 73.696 \\
$17.00-18.00$ & 3329 & 1785.1 & 23.06 & 60.471 & 0.5103 & 77.421 \\
$17.15-18.15$ & 3329 & 1781.5 & 22.70 & 60.471 & 0.5093 & 78.464 \\
$17.30-18.30$ & 3329 & 1760.9 & 22.70 & 60.471 & 0.5034 & 77.557 \\
$17.45-18.45$ & 3329 & 1761.7 & 22.33 & 60.471 & 0.5036 & 78.895 \\
\hline $18.00-19.00$ & & & &
\end{tabular}

Dari Tabel 6 dapat juga diambil perbandingan antara kepadatan dengan kecepatan rata-rata pada Jalan Danau Sunter Selatan untuk menghitung kapasitas jalan pada jalan tersebut. Perbandingan kepadatan dengan kecepatan rata-rata dapat dilihat pada Gambar 3.

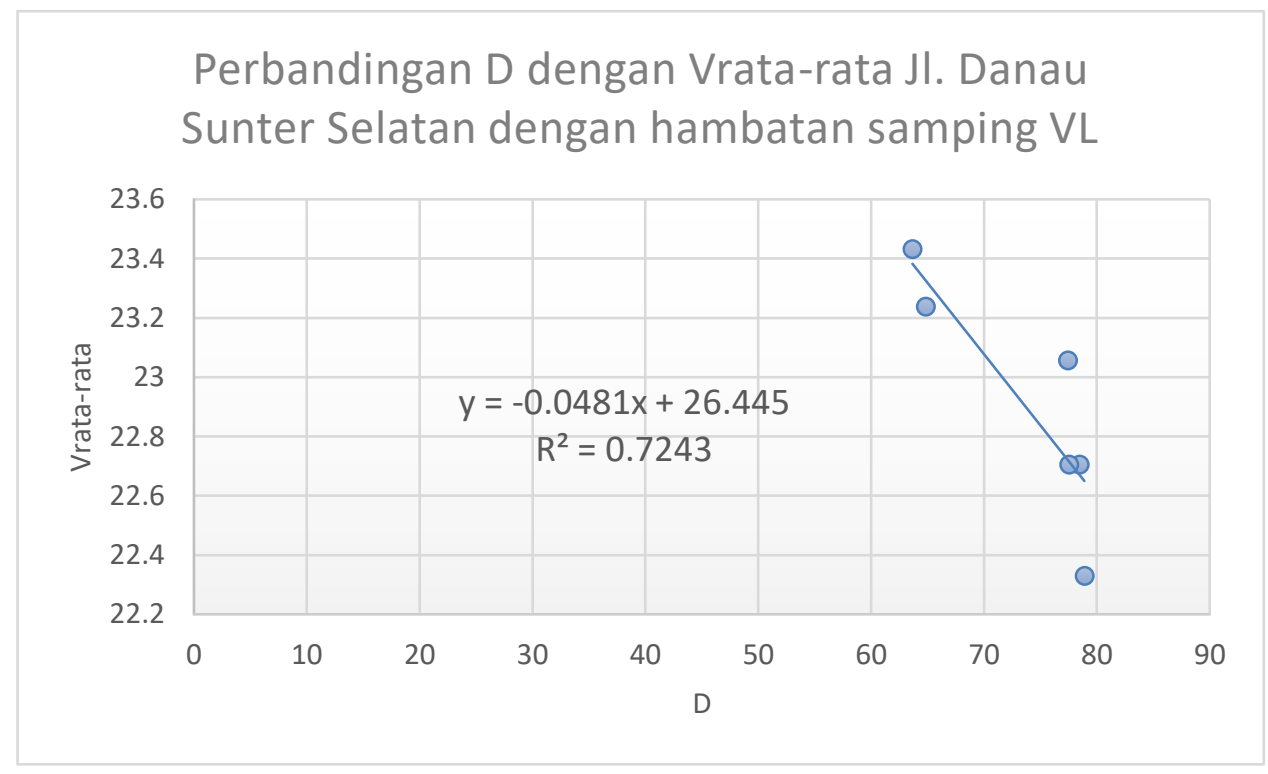

Gambar 3. Perbandingan D Dengan V Rata-Rata Jalan Danau Sunter Selatan 


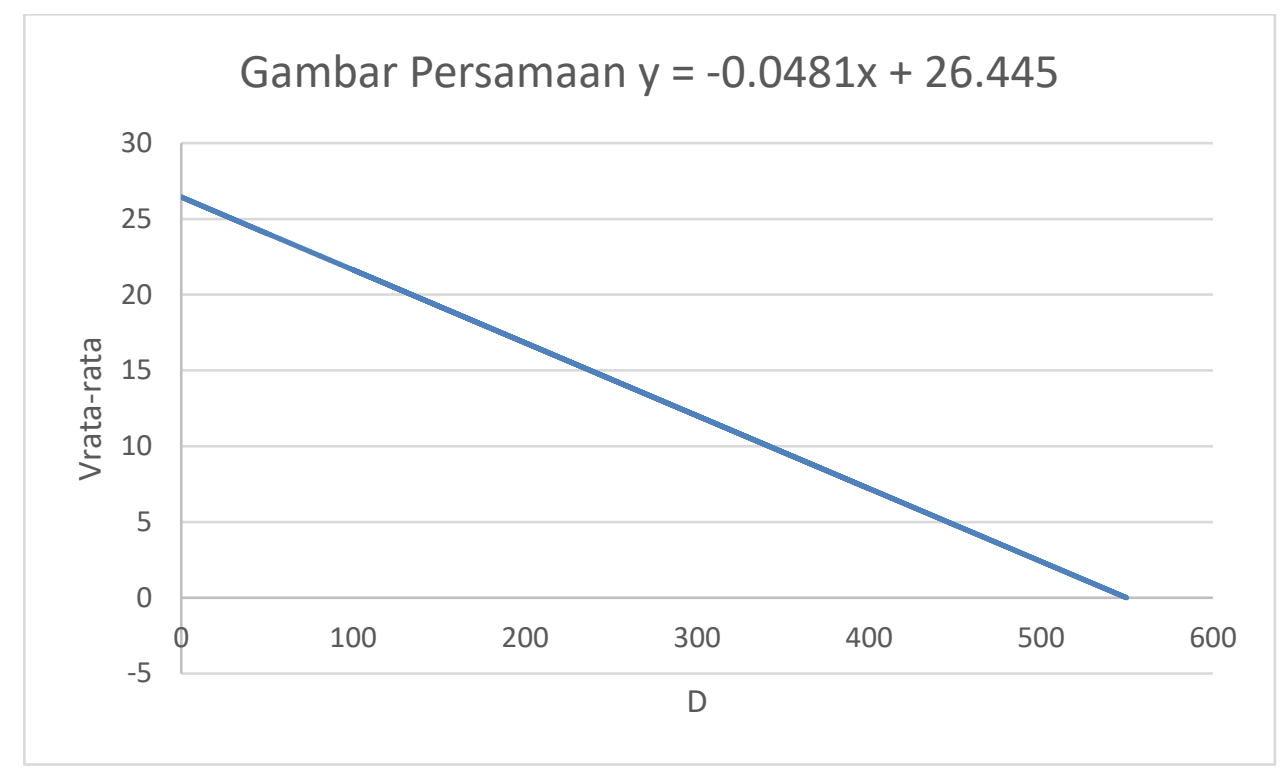

Gambar 4. Hubungan kepadatan dengan kecepatan

Dari Gambar 4 maka didapatkan nilai Dj 549.792 kendaraan/km merupakan nilai x maksimum, dan Vf $26.445 \mathrm{~km} / \mathrm{jam}$ merupan nilai y maksimum maka $\mathrm{C}$ yang didapat 3635 kendaraan.

Performa dan kepadatan lalu lintas pada Jalan H. Encep Nawawi dapat dilihat pada Tabel 7.

Tabel 7 Performa dan Kepadatan Lalu Lintas Jalan Hj. Encep Nawawi

\begin{tabular}{ccccccc}
\hline Jalan & \multicolumn{7}{c}{ Jl H.Encep Nawawi Bogor } \\
\hline Tata Guna Lahan Kiri & \multicolumn{5}{c}{ Toko dan rumah } \\
\hline Tata Guna Lahan Kanan & $\mathrm{C}$ & $\mathrm{Q}$ & V rata-rata & $\mathrm{FV}$ & $\mathrm{Q} / \mathrm{C}$ & $\mathrm{D}(\mathrm{Q} / \mathrm{V})$ \\
\hline Pukul & 3201 & 683.1 & 31.01 & 52.77 & 0.213 & 22.030 \\
\hline $06.00-07.00$ & 3201 & 696 & 31.01 & 52.77 & 0.217 & 22.446 \\
$06.15-07.15$ & 3201 & 740.8 & 31.01 & 52.77 & 0.231 & 23.891 \\
$06.30-07.30$ & 3201 & 782.9 & 31.69 & 52.77 & 0.245 & 24.705 \\
$06.45-07.45$ & 3201 & 861.8 & 31.11 & 52.77 & 0.269 & 27.699 \\
$07.00-08.00$ & 3201 & 1040.5 & 31.33 & 52.77 & 0.325 & 33.207 \\
$11.00-12.00$ & 3201 & 1045.6 & 30.98 & 52.77 & 0.327 & 33.753 \\
$11.15-12.15$ & 3201 & 1063.5 & 30.08 & 52.77 & 0.332 & 35.361 \\
$11.30-12.30$ & 3201 & 1086.4 & 29.17 & 52.77 & 0.339 & 37.241 \\
11.45 .12 .45 & 3201 & 1113 & 29.17 & 52.77 & 0.348 & 38.153 \\
$13.00-14.00$ & 3201 & 1141.3 & 29.40 & 52.77 & 0.357 & 38.820 \\
$17.00-18.00$ & 3201 & 1113.1 & 29.40 & 52.77 & 0.348 & 37.861 \\
$17.15-18.15$ & 3201 & 1121.1 & 29.70 & 52.77 & 0.350 & 37.747 \\
$17.30-18.30$ & 3201 & 1121.4 & 29.12 & 52.77 & 0.350 & 38.506 \\
$17.45-18.45$ & 3201 & 1122 & 28.55 & 52.77 & 0.351 & 39.305 \\
$18.00-19.00$ & & &
\end{tabular}

Dari Tabel 7 dapat juga diambil perbandingan antara kepadatan dengan kecepatan rata-rata pada Jalan Hj Encep Nawawi untuk menghitung kapasitas jalan pada jalan tersebut. Perbandingan kepadatan dengan kecepatan rata-rata dapat dilihat pada Gambar 5 . 


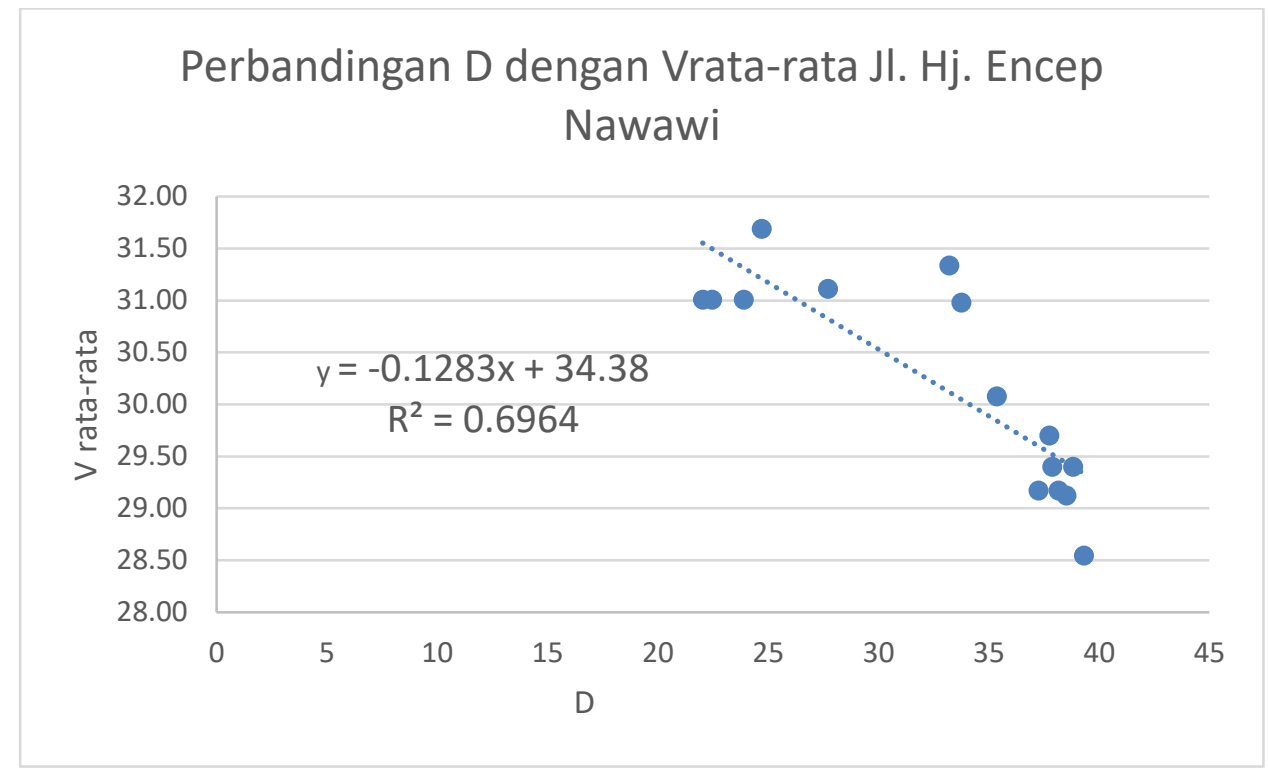

Gambar 5. Perbandingan D Dengan V Rata-Rata Jalan Hj. Encep Nawawi

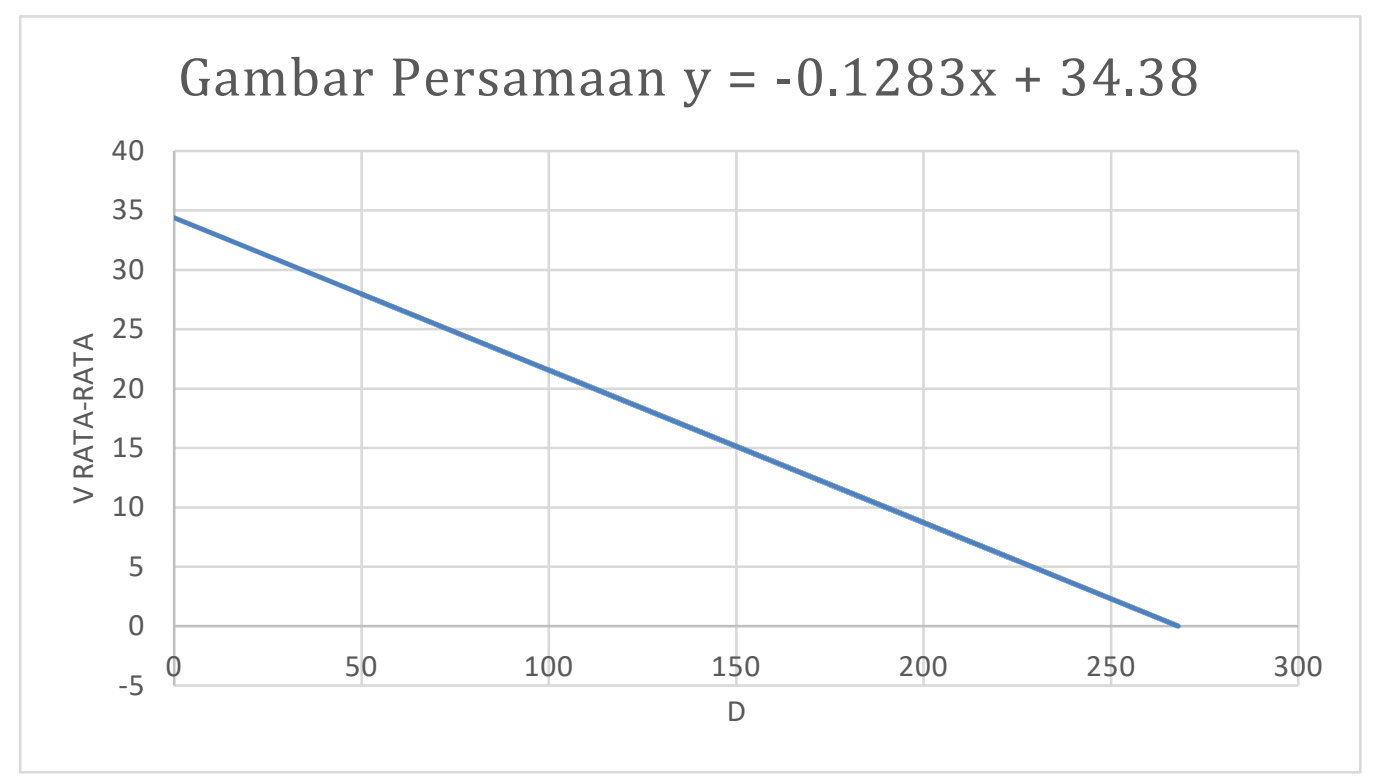

Gambar 6. Hubungan kepadatan dengan kecepatan

Dari Gambar 6 maka didapatkan nilai Dj 267.965 kendaraan/km merupakan nilai x maksimum, dan Vf 34.38 km/jam merupan nilai y maksimum maka $\mathrm{C}$ yang didapat 2303 kendaraan. 


\section{Perbandingan Nilai Kapasitas Antara MKJI dan Survei}

Tabel 8. Perbandingan Kapasitas Berdasarkan Perbedaan Hambatan Samping Dengan Metode MKJI dan Hasil Survei

\begin{tabular}{|c|c|c|c|c|c|c|}
\hline \multirow[b]{3}{*}{ Hambatan Samping } & \multicolumn{4}{|c|}{ Jakarta } & \multicolumn{2}{|c|}{ Bogor } \\
\hline & MKJI & Survei & MKJI & Survei & MKJI & Survei \\
\hline & \multicolumn{2}{|c|}{ Bungur Besar } & \multicolumn{2}{|c|}{ Danau Sunter Selatan } & \multicolumn{2}{|c|}{ Hj. Encep Nawawi } \\
\hline VL & & & 332 & 3635 & 3201 & 2303 \\
\hline $\mathrm{L}$ & & & 32 & 2423 & & \\
\hline M & 3192 & 1658 & & & & \\
\hline
\end{tabular}

Nilai kapasitas berdasarkan MKJI dan hasil survei akan dibandingkan dengan nilai hambatan samping dan perbedaan ukuran kota. Dari Tabel 8 dapat dilihat jika pada data survei jalan Danau Sunter Selatan dengan jalan yang sama namun dengan nilai hambatan samping yang berbeda terdapat perbedaan kapasitas dimana pada jalan 4/2TT semakin banyak hamabatan samping maka kapasitas jalan akan menjadi semakin kecil hal ini membuat survei memiliki kecerencungan yang sama dengan MKJI. Untuk ukuran kota membandingkan jalan di Jakarta dan Bogor maka dapat dilihat dengan tipe jalan yang sama dimana yang membedakan hanya ukuran kotanya saja dari hasil survei didapatkan jika pada jalan 4/2TT semakin besar ukuran kota maka kapasitas juga menjadi semakin besar hal terseebut juga membuat survei memiliki kecerendungan yang sama dengan MKJI.

\section{KESIMPULAN}

Adapun kesimpulan dari hasil analisis dalam penelitian ini yaitu:

1. Berdasarkan hasil survei maka didapatkan pada jalan 4/2 D semakin banyak populasi suatu kota maka kapasitasnya akan semakin besar maka hasil ini membuktikan kecerendungan ya sama dengan MKJI.

2. Berdasarkan hasil survey dan MKJI dapat disimpulkan bahwa MKJI masih dapat digunakan untuk menghitung jalan 4/2 D di Jakarta dan Bogor.

3. Besar kemungkinan faktor koreksi pengaruh ukuran kota lebih besar di MKJI hal ini dibuktikan dengan jika pada 4/2D untuk hambatan samping VL dari MKJI pengaruh nilai datanya didapat 1.04 namun berdasarkan hasil survei nilai maka perbedaannya menjadi 1.578 .

4. Besar kemungkina nilai hambatan lebih besar di MKJI hal ini dibuktikan dengan jika pada 4/2D untuk hambatan samping VL dan L pada Jl. Danau Sunter Selatan dari MKJI perbandingan pengaruh nilai kapasitas antara hambatan samping VL dan L didapat 1.01 namun berdasarkan hasil survei nilai maka perbedaannya menjadi 1.5 .

5. Metode Green Shield pada tipe jalan 4/2 UD tidak dapat diaplikasikan dengan baik hal ini dibuktikan dengan nilai $\mathrm{R}^{2}$ yang kecil.

6. Pada penelitian model Green Shield tidak dapat diaplikasikan dengan baik dikarenakan ada beberapa data yang memiliki korelasi determinan yang tidak baik.

7. Persamaan MKJI dan konsep PKJI adalah memilik angka parameter setiap faktor yang mirip dan memiliki metode perhitungan kapasitas dan arus bebas yang sama.Perbedaan MKJI dan konsep PKJI adalah pada perbedaan penyebutan notasi, pada kategori kendaraan di konsep PKJI diperkenalkan kategori kendaraan sedang (KS), dan pada konsep PKJI beberapa nilai parameter untuk faktor pengaruh tipe jalan 4/2TT sudah ditiadakan.

\section{DAFTAR PUSTAKA}

Direktoral Jendral Bina Marga. (1997). Manual Kapasitas Jalan Indonesia (MKJI). Direktorat Bina Jalan Kota, Direktorat Bina Marga RI dan SWEROAD, Jakarta.

Direktorat Jenderal Bina Marga. (2014). Pedoman Kapasitas Jalan Indonesia (PKJI), Jakarta.

Lalenoh, H dan Rusdianto, (2015). Analisa Kapasitas Ruas Jalan Sam Ratulangi.

Miro, F. (2005). Perencanaan Transportasi untuk Mahasiswa, Perencana, dan Praktisi. Erlangga, Jakarta.

Najid. (2015). Evaluasi Penentuan Kapasitas Jalan Berdasarkan Metode MKJI. FT. Teknik Sipil Universitas Tarumanagara, Jakarta.

Najid. (2016). Evaluasi dan Penentuan Nilai Satuan Mobil Penumpang Pada Manual Kapasitas Jalan Indonesia. FT. Teknik Sipil Universitas Tarumanagara, Jakarta. 
Survei

Pemerintah Indonesia. (2004). Undang-Undang No. 38 Tahun 2004 Tentang Jalan. Lembaran Negara RI Tahun 2004, No. 38. Sekretariat Negara, Jakarta.

Tamin, O.Z. (2000). Perencanaan dan Pemodelan Transportasi, Edisi kedua. Jurusan Teknik Sipil Institut Teknologi Bandung, Bandung. 